\title{
Climate Change Resilience and Adaptation: Perspectives from a Century of Water Resources Development
}

DOI:

10.3167/ares.2010.010108

\section{Document Version}

Accepted author manuscript

Link to publication record in Manchester Research Explorer

\section{Citation for published version (APA):}

Agnew, C. T., \& Woodhouse, P. (2010). Climate Change Resilience and Adaptation: Perspectives from a Century of Water Resources Development. Environment and Society: Advances in Research, 1(1), 156-183.

https://doi.org/10.3167/ares.2010.010108

\section{Published in:}

Environment and Society: Advances in Research

\section{Citing this paper}

Please note that where the full-text provided on Manchester Research Explorer is the Author Accepted Manuscript or Proof version this may differ from the final Published version. If citing, it is advised that you check and use the publisher's definitive version.

\section{General rights}

Copyright and moral rights for the publications made accessible in the Research Explorer are retained by the authors and/or other copyright owners and it is a condition of accessing publications that users recognise and abide by the legal requirements associated with these rights.

\section{Takedown policy}

If you believe that this document breaches copyright please refer to the University of Manchester's Takedown Procedures [http://man.ac.uk/04Y6Bo] or contact uml.scholarlycommunications@manchester.ac.uk providing relevant details, so we can investigate your claim.

\section{OPEN ACCESS}




\title{
Climate change resilience and adaptation, perspectives from a century of water resources development.
}

(author-accepted copy, published 2011 in Environment and Society: Advances in Research. 1, 1, p. 156-183)

Authors: Clive Agnew and Philip Woodhouse, University of Manchester

\begin{abstract}
:
The Fourth Assessment the Inter-Government Panel on Climate change states "Warming of the climate system is unequivocal". The alarming environmental, social and economic consequences have been reinforced by the influential Stern report, calling for immediate action from individuals, institutions and governments. This paper identifies parallels between the problem of adaptive management presented by climate change and an earlier 'global water crisis', and explores how adaptive strategies have successively emphasized three different principles, based on 'science' (the ecological principle), economics (the instrument principle) and politics/institutions (the institutional principle). The paper argues that the close association between climate change and water resources development enables a comparative analysis to be made between the strategies that have been adopted for the latter over at least the last 100 years which informs our understanding of the challenges facing adaptations in the face of future global warming. It argues that the experience of water resource development suggests a strong interdependence between the three principles and argues that conceptualizing them as different dimensions of a single governance framework is necessary to meet the challenge of climate change adaptation.
\end{abstract}

\section{Introduction}

The IPCC have produced four key reports (IPCC, 1990, 1995, 2001, 2007), providing increasing evidence that $20^{\text {th }}$ Century changes in the Earth's climate are unprecedented in historic times. In this work, physical models and empirical evidence have in recent decades established links between atmospheric concentration of greenhouse gases and temperature rises , and the IPCC (2007: 30) has argued strongly that:"Warming of the climate system is unequivocal, as is now evident from observations of increases in global average air and ocean temperatures, widespread melting of snow and ice and rising global average sea level". Although this represents a broad scientific consensus, skeptics remain, and Hulme (2009: 1) noted that, in the UK: 'only 41\% believed humans are causing climate change, 32\% remained unsure and 15\% were convinced we aren't.' This explains the recent vigorous defence of the science of global warming conducted, online as well as in academic publications, by institutions such as the UK Meteorological Office (2010) and the Royal Society (2008). The science forms the basis of alarming predications of social and economic consequences, such as those in the influential Stern report (2006), which assumed a $2{ }^{\circ} \mathrm{C}$ rise in global temperature. Yet Anderson and Bows (2008) argue that this understates the likely scale of impacts because past accumulation of greenhouse gas has already reached levels which will see temperatures inexorably heading past the $2{ }^{\circ} \mathrm{C}$ 'tipping point', beyond which many believe warming causes serious disruptions to human activities and natural ecosystems, and will most likely exceed a $4{ }^{\circ} \mathrm{C}$ warming during the $21^{\text {st }}$ Century. 
Predicted consequences are so great that most political leaders support the need for action to curb future emissions. However, the system of financial incentives agreed at Kyoto in 1997 and thereafter is widely regarded to have been ineffective, and agreement on coordinated action to replace it appears elusive, as exemplified by widespread disappointment with the Copenhagen conference of 2009 (Guardian 2009). Dimitrov's (2010: 796) view of the Copenhagen agreement is not uncommon: "a failure whose magnitude exceeded our worst fears and the resulting Copenhagen Accord was a desperate attempt to mask this failure". This depressing analysis, and a renewal of public questioning of the IPCC's scientific methodology, forms the backdrop against which individuals, institutions and governments must act to respond to the threats posed by predicted future global warming.

Two broad strategies emerging from UN deliberations, and promoted by the IPCC to tackle global warming, are: 'mitigation' and 'adaptation'. Mitigation seeks to reduce atmospheric greenhouse gas emissions through emission control and technological change, for example to achieve greater environmental absorption and storage, whereas adaptation is seen to concern changing human behaviour in response to predicted threats. Mitigation strategies are not without criticism, but there is strong support for the economic measures associated with them, such as carbon trading and carbon offsets, if only because poorer nations hope this will provide much needed financial support, while governments of richer countries hope it will minimize the economic (and political) cost of reducing emissions. Adaptation has been promoted as necessary to increase the ability of people and ecosystems to survive the 'shocks' associated with climate change. However, there is also some confusion, not least because 'mitigation' includes elements of adaptation, such as changes in energy consumption, waste reduction and the like, alongside economic incentives for investment in technological change. Similarly, adaptation strategies also utilize technical solutions which have to be funded, hence economic tools are part of the adaptation debate.

What is clear in discussions over mitigation and adaptation is that favoured strategies are concerned both with technological change and also influencing human behavior through a variety of instruments that include both financial and regulatory measures. In this paper we argue that similar conclusions can be drawn from an examination of water resources development, which over the $20^{\text {th }}$ Century has sought to manage the hydrological cycle based initially on science and engineering but more recently through (re)designing systems of water governance (Plummer and Slaymaker, 2007). The aim of this paper is to use the experiences gained over at least the last 100 years from tackling water resource problems from a variety of perspectives, and to apply and contrast these to more recent concerns about the impacts of global warming emerging over recent decades. Water resources and climate are obviously linked through hydrological cycles and energy exchanges between earth and atmosphere, but more than this, we argue, they share common management approaches based around the notions of resilience and governance of ecosystem resources that can help us to gain critical insights into strategies to combat climate change. The paper initially reviews predicted impacts of climate change on water resources to explore the continuum between atmosphere and hydrology, and to demonstrate why strategies developed to tackle flood risk and water scarcity may be relevant to current attempts to respond to global warming. We then turn to a discussion of resilience and governance which is used to present three principles of environmental management: scientific, embracing an 'ecological principle'; neoliberal, embracing an economic, or 'instrument', principle; neoinstituional embracing an 'institutional principle'. We use these three principles to structure the rest of the paper which systematically considers first the lessons from water resources development and then contrasts these with current approaches to climate change adaptation. 


\section{Climate change and water resources}

The IPCC has concluded in both its Third Assessment (2001) and Fourth Assessment (2007) reports that freshwater resources are being affected by climate change. Future predictions include decline in glacier storage and increases in the occurrence of precipitation extremes, leading to more droughts and more floods. Increased runoff of $10-40 \%$ is predicted in higher latitudes and wet tropics, $10-30 \%$ more in dry tropics. The greatest regional changes are likely to occur in Africa, where increasing water stress is expected, and Australia is also likely to experience water security problems through reduced precipitation. In Asia, decreased meltwater flows are likely to offset climate conditions otherwise favourable to increased crop yields. The three key manifestations of climate change in relation to freshwater resources are rising sea levels, increased flood hazards, and increased drought incidence.

\section{Sea-level rise}

Freshwater resources are threatened by sea level rises, both by surface flooding in coastal areas and saline intrusion into groundwater. Gregory and Lowe (2000) forecast a rise of around $40 \mathrm{~cm}$ from 1990 to 2100 with $15 \mathrm{~cm}$ already observed during the $20^{\text {th }}$ Century (Dessler and Parson, 2006). More controversially, Meir et al (2007) suggest that previously unaccounted contributions through glacial melting will add a further 10 to $25 \mathrm{~cm}$ sea level rise by 2100 , or $50 \%$ more than the IPCC (2007) overall projections of 20 to $50 \mathrm{~cm}$ (Oppenheimer etal 2007; Solomon etal, 2008). As 100 million people live less than $1 \mathrm{~m}$ above sea level and $40 \%$ of the world's population live within 60 miles of the coast this is a serious threat especially in areas of South East Asia (Dow and Downing, 2006). As with the hundreds of millions predicted to be exposed to increased water stress, however, the actual impact will depend upon human capacity to respond and adapt to these changing threats.

\section{Flood hazard}

The IPCC (2007) report it is likely that up to $20 \%$ of the world's population will inhabit areas where flood risk has increased due to climate change. There is evidence precipitation has increased in eastern areas of the Americas, northern Europe and central Asia while it has decreased in southern Asia, Southern Africa and the Mediterranean. It is also highly likely that for glacier- and snow-fed areas runoff has increased while rivers have warmed. In general, higher storm flows can be expected to result from global warming, as explained by Arnell (2002 and 2003) and Kerr (2007). However, even where increased precipitation causes higher runoff this water resource benefit is likely to be moderated by increasing variability and seasonal changes. Considerable uncertainty is attached to predictions of river flow since conversion of precipitation changes into river flood concerns change to extremes of two variables: intensity and duration (Bell etal, 2007; Prudhomme etal, 2002). There are also spatial differences: in the UK, for example, upland catchments have proved easier to model than lowland catchments where groundwater input is more significant. Similarly, rural and urban climate may be distinct (Arnfield ,2003 and Roth (2007). Impacts in urban areas are a significant challenge because of the complex nature of the urban hydrological system (Marsalek etal, 2006) with combined threats of fluvial flooding (from river channels) and pluvial floods (from higher rainfall intensity and poor urban drainage infrastructure).

\section{Drought}

The IPCC (2007) have identified drought risk as increasing during the $21^{\text {st }}$ Century principally in tropical regions. However, with more extremes in precipitation and drier summers predicted for the northern hemisphere, the incidence of droughts is likely to increase across the globe (Lloyd-Hughes and Saunders 2002). Drought needs to be differentiated from desiccation. The former is a short term and abnormal water shortage due to an imbalance between water supply and demand (Agnew ,2002 ; Wilhite 2000). It can result from a reduction in precipitation but can also arise from changes in human activity that raise demand for water above the available supply. Desiccation refers to increasing aridity as determined through 30 year climate averages. Climate change threatens both increased drought and desiccation. However, adaptation strategies will differ according to whether one 
is dealing with drought, which needs immediate response, or desiccation, which requires longer term strategies.

The areas predicted by the IPCC to be most threatened by increasing drought, and aridity, are areas of high precipitation variability where agriculture is the dominant landuse, in particular sub-Saharan Africa. Southern Africa could lose almost a third of maize production while losses of rice and millet could be over $10 \%$ in south Asia. Impacts and possible responses are not straightforward, however, and Challinor etal (2009) and Soussana etal (2010) both argue the need for improvements in agro-climate modeling. Drought effects on crop growth may be tackled through irrigation and other technologies if they can be afforded (Parry etal 2005). However, crop choice has a significant effect on drought hazard, and a warming world with higher carbon dioxide levels also heralds other changes. For example, crops such as wheat, soyabean and rice ("C3 plants" because $\mathrm{CO}_{2}$ is fixed by a 3 carbon compound phosphoglyceric acid) are well placed to respond positively because they have lower water-use efficiencies compared to typical dryland crops such as millet or sorghum . Thus a $\mathrm{CO}_{2}$ richer world means greater growth potential for some plants in temperate areas, but only if there is sufficient water to offset the impacts of higher temperatures. A further factor is that vulnerability of poorer areas of sub-Saharan Africa to water scarcity may be increased where production systems are geared to global economic linkages rather than to local risk factors (Glantz, 1994; Franke and Chasin, 1980). The interaction of socioeconomic and biophysical factors in determining overall vulnerability prompted Thornton etal (2006) to argue for a move beyond considering only water supply when deciding upon drought management strategies. Similarly, TERI (2003) suggest three forms of drought vulnerability: biophysical, social and technological.

These concerns about climate change intersect with perceptions of a 'global water crisis' (UN World Water Development Report, 2009) identified with failure to meet demand for water from a more populated and urbanized world (World Water Council, 2010), and the commitment included in the United Nations Millennium Development Goals (MDG, 2000) to reduce by half the proportion of the global population lacking access to clean water and adequate sanitation, numbering some 1.1 billion and 2.6 billion people, respectively (HDR, 2006). This 'crisis' narrative is problematic, however, for two reasons. 
Firstly, the focus on domestic water needs, as in the MDG, raises questions of what standard to use. The WHO (Howard and Bartram, 2003) state that a water supply of 20 litres per person per day (Icd) will only provide sufficient for drinking and basic hygiene whereas a supply, from a source no more than $1 \mathrm{~km}$ away, of at least $50 \mathrm{lcd}$ is required to meet most essential water needs. In practice, measured water consumption values are greater, typically around $100 \mathrm{lcd}$ from urban street standpipes (Twort etal, 2002), rising to 300 to $500 \mathrm{lcd}$ for developed countries and even up to $800 \mathrm{Icd}$ (in USA). The range of values poses questions about how those already facing water scarcity can possibly adapt to a warmer, drier world, and how higher levels of demand typical of urban households can be met. This last is significant because most of the future global population growth is expected to take place in cities, of which 21 megacities each have populations already exceeding 10million. Against this, Pott's (2009) work concludes that urbanization trends in Africa are less than commonly represented, especially in medium-sized towns where most of the observed increases are due to local population growth and not in-migration.

A second problem with the 'water crisis' narrative expressed in terms of domestic use, as in the MDG, is that, in terms of total water withdrawal, agriculture (and therefore rural areas) dominates with $70 \%$ of global extraction, (industry $22 \%$ and domestic use $8 \%$ ). Moreover, the pattern of rising withdrawals is not reproduced everywhere. For example in the USA total water withdrawals reached a plateau in the 1980s (USGS, 2005), while household water consumption in the UK has remained around 150 lcd since the mid 1990s (Ofwat (2007).

Nonetheless, since the eighteenth century global demand for water has grown 35-fold whereas population has increased eight-fold (Altinbilek, 2002). There are undoubtedly problems of water scarcity in some parts of the world, most obviously in arid regions. Twenty nine countries are classified as being 'water stressed' in terms of the amount of water annually available for all economic activity (less than 1,700 $\mathrm{m}^{3} \mathrm{c}^{-1} \mathrm{y}^{-1}$ ). This list includes India and Denmark but also many of the poorest developing countries. A further 17 countries, mainly from the Middle East and North Africa, are classified as facing 'water scarcity' (less than $1000 \mathrm{~m}^{3} \mathrm{c}^{-1} \mathrm{y}^{-1}$, based on WRI 2007 data). As a consequence a major concern emanating from future climate scenarios is that changes to water supply will be amongst the biggest challenges, coupled to increases in demand for both food production and a growing urban population. While concern over global warming is relatively recent, the need to manage and adapt to water resource constraints is not new and this presents an opportunity to learn from past methods of adaptation to different environmental conditions. In the next section we outline a framework to identify different dimensions of adaptation.

\section{Governance, Resilience and Water Development Principles}

Governance is a key concept in adaptation strategies. It is essentially about how decisions are made. Reed and Bruyneel (2010:647) observe that the meaning of governance differs between an emphasis upon government as a centralized authority deploying financial and regulatory instruments and, in contrast, concepts of devolved decision making by people and communities. They further note a distinction between 'governance' and 'management', which is presented as operational procedures. Figure 1 depicts three elements of water governance as presented in the UN's World Water Development Report (2006). Recent reports on water resources development have stressed the importance of effective governance, as exemplified in the EU Water Framework Directive (2000) and repeated in the third UN World Water Development Report (WWDR, 2009). It should be noted that figure 1 presents a normative view of environmental management, whereas in practice markets are not perfect, environments degrade and equity is rarely achieved. Nevertheless it illustrates an integrated approach that combines environmental, economic and social dimensions. To 
the extent that these dimensions are combined successfully, we might draw the same diagram with 'sustainability' in the centre, or even resilience. This is not to say governance is the same as sustainability or 'resilience' (see below), but that good and effective governance is a requisite for the latter.

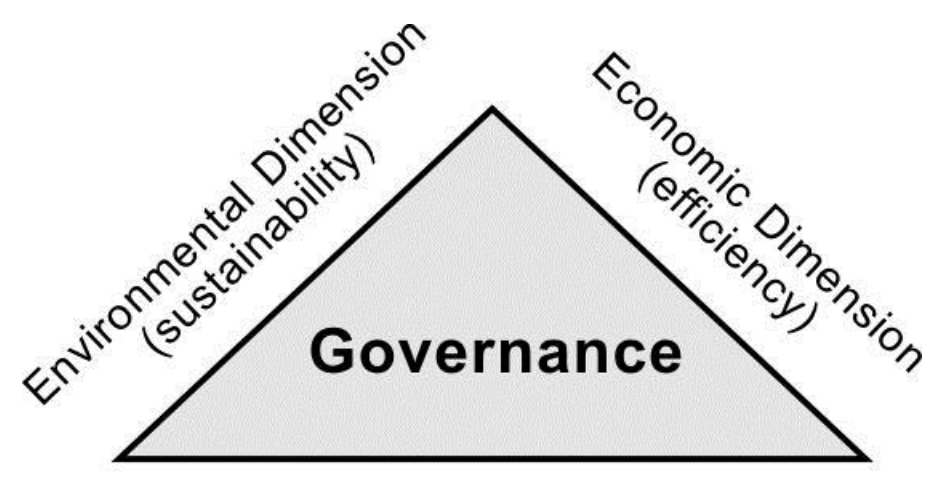

Social and Political Dimension

(equity and democracy)

Figure 1 Dimensions of Water Governance (after WWDR, 2006)

The need for an integration of these dimensions for effective environmental management has formed the basis for thinking about water development since a recasting of water development priorities emerged from the International Conference on Water and the Environment (ICWE), held in Dublin in 1992, and were subsequently incorporated into the Earth Summit held in Rio De Janerio in the same year (Lundqvist, 2000 and UNCED, 1992). The principles emerging from the ICWE have been reworked, notably through incorporation of gender issues into the third principle (WWC, 2000). They typically include:

- An 'ecological principle' that recognizes the need for holistic management of the water resource, usually interpreted as managing water in an 'integrated' way, according to its hydrological units, such as river basins or subterranean aquifers. Here scientific management and expert decision making is the norm, generally invoking the agency of a Weberian state model to ensure that individual, smallerscale, actions are subordinated to a 'greater good', defined variously in ecological, political/security, or economic terms.

- An 'instrument principle' which recognizes water as an economic good whose efficient use and conservation should be promoted by charges payable by users. Here neo-liberal ideas, whose resurgence in the 1980s coincided with the concept of 'sustainable development', are embraced, notably through the use of water pricing as a means of determining allocation priorities and the valuation of ecological services.

- An 'institutional principle' that calls for decision-making on water resources to be decentralized to the smallest scale feasible, following criteria of subsidiarity, and to 
be representative of all water users. Here importance is attributed to decentralized and participatory decision-making processes.

It is possible to map these principles onto the development of water resources. Within the environmental, or biophysical dimension we can locate the engineering approaches that dominated water resource development from early water treatment, some four thousand years ago (Symons (2006) to the first municipal water treatment plant in Scotland early in the $19^{\text {th }}$ Century. Walski, (2006) charts this technological development of water supply, noting that two thousand years ago cities in Asia had functioning water systems long before the development of modern hydraulic engineering in the $19^{\text {th }}$ Century. Today a plethora of water control technologies are available to tackle environmental constraints, from megadams (Altinbleck 2002), desalination (Burbano etal 2007) and even cloud seeding (Silverman, 2003). However, this emphasis upon hydrology and engineering has become substantially counterbalanced, if not replaced, by the 'instrument principle' and the 'institutional principle'. This has shifted focus to water allocation, on the one hand through pricing mechanisms, and in the other through 'deliberative' decision-making in which all water users or 'stakeholders' are represented. The category of stakeholders is typically drawn widely, to include all those whose interests, such as amenity value, may be affected by the water use of others. Women were explicitly identified as needing stronger representation in water management, in recognition of the strongly gendered nature of the labour of providing household water supplies in many societies, (Peter, 2006). Together, the instrument and institutional principles have shifted attention from technology to governance. This shift, which Renzetti (2002) traces to the middle of the $20^{\text {th }}$ Century, is evident in the historical development of water supply identified by Swyngedouw (2006):

- Small scale supply enhancement through private investors for profit, up to 1850 s in Western (OECD) countries.

- Large scale municipal sanitation and potable supply development, up to 1920 s.

- National scale public provision of basic needs and economic development, up to 1970s.

- Privatisation and water an economic good, post 1970s.

For the first three of these stages, financing and organization of water resource development was driven primarily by the increasing scale of engineering works needed to meet growing urban demand during the $19^{\text {th }}$ and early $20^{\text {th }}$ century. Only since the last quarter of the $20^{\text {th }}$ century has investment in water become guided by neo-liberal ideas of pricing and costrecovery, indicated as the final stage in the above chronology. Over the past two decades this primacy of neo-liberal models of market-based management, has, in turn, become increasingly contested on the ground that it does not satisfy social goals for universal access to adequate water, as reviewed by Agnew and Woodhouse (2011).

We argue there are strong parallels between water resources development and responses to climate change, in that both were initially focused upon scientific evidence leading to technological solutions, followed by economic instruments to provide incentives for change via 'commodification', with finally a move to embrace institutional /political mechanisms based on considerations of social inclusion and equity. In figure 2 we have presented these three principles as key instruments for maintaining 'resilience' in the face of climate change impacts. In contrast to figure 1, we have introduced a fourth element 'hazards' in figure 2 to acknowledge that not all environmental or climate change necessarily has a destructive nature. Environmental change is thus not synonymous with impacts that require an adaptive response.

\section{Resilence}

The concept of resilience - the ability to respond to environmental shocks - is attributed to the ecologist Holling (1973). It is defined by IPCC (2008:880) as "The ability of a social or 
ecological system to absorb disturbances while retaining the same basic structure and ways of functioning, the capacity for self-organisation, and the capacity to adapt to stress and change." It has been found useful in work on climate changes because it recognizes that the same climate change might produce different impacts because of variations in stability and vulnerability of different social or ecological systems. Resilience has, for example, been incorporated into work by ILRI on mapping climate vulnerability and poverty in Africa (Thornton et al 2006).
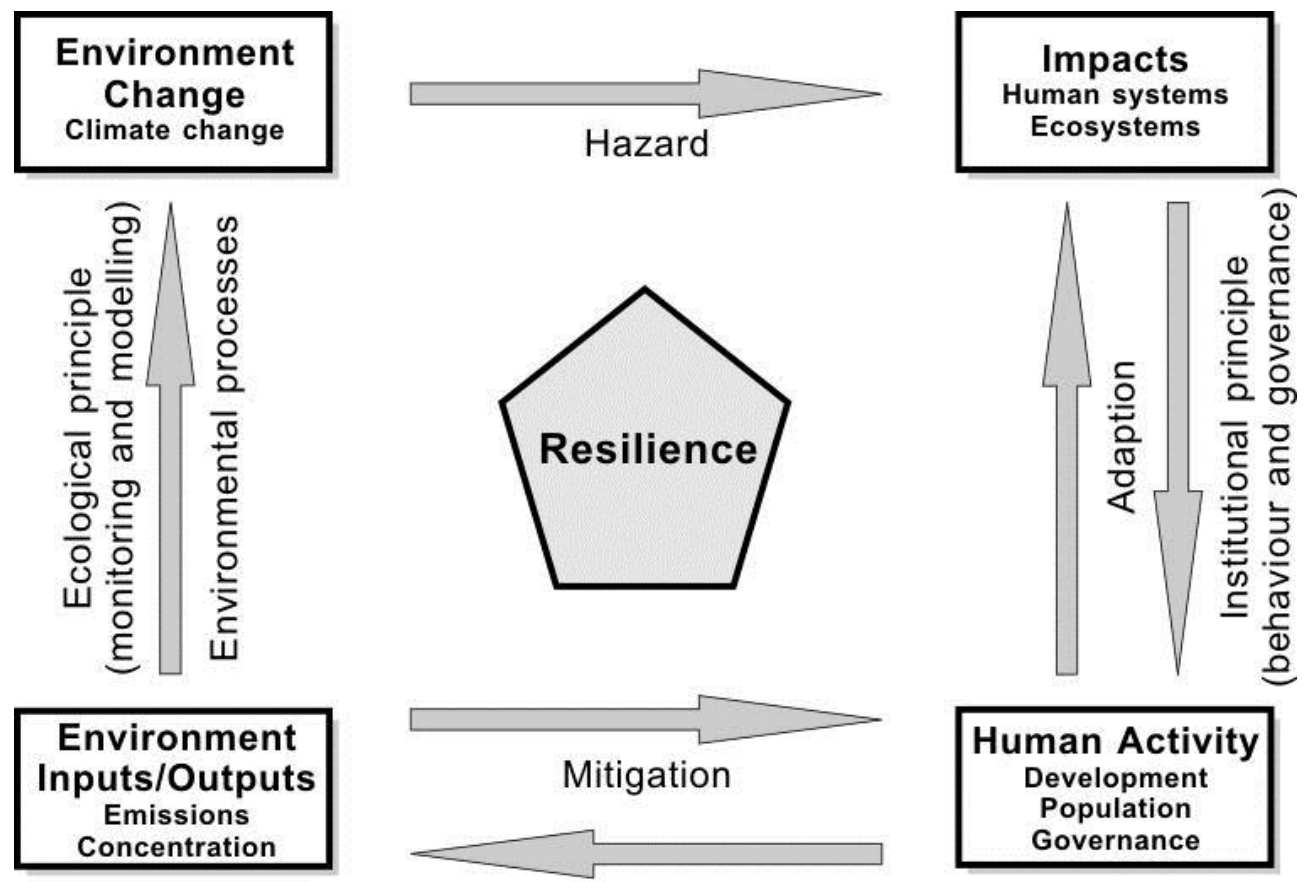

Instrument principle (pricing and investments)

Figure 2 Framework for understanding responses to climate change using ecological, instrument and institutional principles.

** change 'environmental processes' for 'scientific management' **

Pelling's recent review of resilience (2011:42-43) notes that it is "not simply synonymous with adaptation". This is illustrated by an example where (short-term) risk management can lead to (longer-term) institutional inertia, which highlights the need to understand the "social processes shaping resilience". Figure 2 has the merit of illustrating that adaptation and mitigation measures are part of a continuum linking human impacts and actions to resilience. Perhaps more controversial is the choice of three water development 'principles' (ecological, instrument and institutional) to label particular types of engagement. While over-simplified, as discussed below, this framework provides an opportunity to identify key management dimensions underpinning resilience in the face of climate change, and how different climate change responses can be mapped onto different paradigms for natural resource management. The paper now deals with each of the three principles in turn, each section commencing with a discussion of the lessons from water resources development before turning to consider the possible implications for climate change adaptation. 


\section{Ecological Principle (scientific management)}

Some have challenged the 'global' nature of the water crisis (Agnew and Woodhouse, 2011 and Rogers etal 2006), suggesting this focus ignores the successful application of science and technology in many places, bringing not only water to areas of potable need, but also supporting massive increases in food supply through irrigation and sustaining health improvements through sanitation and water treatment. This has been underpinned by, on the one hand, advances in hydrological science, moving from understanding channel flow characteristics to catchment-wide linkages between land surfaces and the atmosphere (Ward and Robinson, 1999 ), and predictive modelling of hydrological variables, most recently based upon artificial neural networks, (Maier etal 2010). On the other hand, developments in the science of water treatment and sanitation from its early origins using filtration and chlorination in $19^{\text {th }}$ century Scotland (McGuire2006, Symons, 2006, Twort etal 2002) has been credited in the USA with a 50 per cent increase in life expectancy during the twentiethcentury (Christman, 1998). Perhaps most emblematic of these engineering achievements are the construction of large dams to supply a five fold increase in irrigated areas during the twentieth century (reaching 277 mha by the Millennium), drinking water for expanding urban centres and $19 \%$ of the world's electric power (Altinbilek, 2002; World Bank, 2009). This remains an important development model (e.g. proposals for economic development in the Ganges-Brahmaputra-Meghna basin (Bandyopadhyay, 2002)), and, although three countries (China, USA and India) dominate, some 45,000 large dams had been constructed in over 150 countries by 2000 . As a result, in less industrialized economies irrigation is often the largest use of water - typically 80 per cent or more (Anand, 2007). However, in the face of increasingly uncertain rainfall, access to irrigation technology, along with fertilizers and new varieties, is an important asset in adaptive strategies (Parry etal, 2005).

The success of scientific - and engineering - led water development means it has provided the model promoted by international development agencies, such UNESCO's International Hydrological Decade (1965-74), and the UN International Drinking Water Supply and Sanitation Decade (1981-90). There has nonetheless been increasing acknowledgement of failure and of unpredictability of outcomes from water development projects in which a topdown management style has given priority to scientific and engineering considerations. Adverse impacts of large scale water developments, and dams in particular, have been documented in detailed case studies (Goldsmith and Hildyard, 1984; World Commission on Dams - WCD, 2000, 2009) that identified many dam projects as failing to reach their goals of HEP production. Altinblek (2002), Nature (2006) and the New Scientist (2008) have also warned of hazards associated with dams and their potential failure, while Ortolano and Cushing's (2002) study of one of the first mega dams, the Grand Coulee, in the USA, concluded the adverse impact upon the indigenous population continues some 70 years later. Questions about sustainability of irrigation have also been raised, particularly with regard to problems of soil salinization and groundwater contamination, leading to declining irrigated area per head of population (Postel, 1992). Even one of the richest areas of the earth, California, has struggled to meet its insatiable appetite for more water through technology. In February 2009 State Governor Schwarzenegger proclaimed a state of emergency as it entered a third consecutive year of low rainfall, with consequent reductions of up to 50 percent in deliveries of water to irrigated agriculture, notably in the San Joaquin valley, with lost agricultural production in 2009 estimated at almost $\$ 1$ billion (CDWR, 2009). Local water shortages are compounded by widespread deterioration in water quality, with only modest improvements achieved between 1993 and 2003 in the most heavily affected streams the USA (Sprague et al., 2009).

Evidence that irrigation did not necessarily benefit all those involved resulted in a shift in focus of irrigation design, particularly in South Asia, from technical considerations of water storage, transmission and application, to issues of poverty, social organisation and 
participation in decision making (Chambers, 1994 check refs). More generally, declining confidence in the ability of engineering design to deliver predictable economic benefits led to growing political opposition to large-scale water projects, and a decline in investment, with support from development banks dropping from $\$ 4.4$ billion a year in the 1980 s to $\$ 2.6$ billion a year by the late 1990s (Bird, 2002). Moreover, despite a renewal of World Bank interest in investment in dams, notably in Africa since 2000 (Pearce, 2006), loans for irrigation and drainage in Africa were lower in 2002-5 than they had been in 1978-81 (CAWMA, 2007: 73).

Large-scale engineering remains an important element of water resources development, especially when HEP is central to cheaper energy production (cf the Three Gorges project in China and Grand Anatolia project in Turkey). More broadly, science and engineering plays a central role in programmes to 're-engineer' rivers in industrialized countries to improve their ecological or flood management functions. However, engineering has come to be seen as part of a continuum in which human organization and behaviour play a much larger role. This is exemplified in proposals for flood responses in the Netherlands (deGraaf etal, 2007) that list four types of adaptive capacity: threshold capacity (engineering to prevent damage, which requires a high degree of social organization); coping capacity (reducing immediate impacts with a focus upon relief, requiring good communication and clear responsibilities); recovery capacity (short term return to previous state, requiring insurance and disaster funds); and adaptive capacity (ability of a community to cope and adjust in the future, which may require significant changes in lifestyle and landuse).

A further key function of science and engineering is evident here: the provision of information relevant to environmental decision-making. As we shall discuss in section 6, 'asymmetries of information' have a major impact on political and institution processes. Thus, environmental 'threats' can become 'institutional facts' that are propagated to support specific landuse policies. Lemos (2003) for example, describes how the threat of drought in Brazil is used to 'insulate' policy makers from public accountability for policy choices they have taken. For our purpose here we need to note that the levels of uncertainty that attach to many types of environmental data have a major influence on such decision-making processes. This has been found to be true of water resource management (e.g. with respect to availability of records of river flows), but is of primary significance when we turn to the science of predicting, and designing responses to, climate change.

\section{Scientific uncertainties and adaptation to climate change.}

Successful adaptation requires stakeholder engagement to have access to the necessary resources, including adequate information to support the mobilization of investment by those developing and implementing climate change policy. Much of this depends upon an understanding that climate change is a threat that will materialise during the $21^{\text {st }}$ Century. It is therefore important to understand the remaining scientific uncertainties, and the impact these may have on stakeholder engagement. The areas of uncertainty can be exemplified by considering the prediction of impacts of climate change on water resources. These may be categorized as: a lack of agreement over how best (which measurements, which variables) to predict change; a more specific problem associated with predicting change at the scale of a region or country; a meteorological data base that is inadequate and deteriorating in certain critical respects. We shall review each of these briefly in turn.

\section{Measuring and predicting climate change}

Although it has long been recognized that the Earth's climate has undergone major changes over geological time scales, current concern centres on the observation that mean global 
temperatures have risen at $0.13^{\circ} \mathrm{C}$ per decade from 1956 to 2005 , or nearly twice the rate observed $\left(0.74^{\circ} \mathrm{C}\right.$ rise in ten decades) for the $20^{\text {th }}$ Century as a whole. The interpretation of this as an accelerating global warming is disputed, and it is worth recalling that only three decades ago climatologists were writing about global cooling (Ponte, 1976). Skeptics' objections include (Oldfield, 2005; Schiermeier, 2010): challenges to historical interpretations of temperature record; that warming trends are much smaller than normal inter-annual temperature variations; that existing climate models are too limited and fail to take sufficient account of feedback mechanisms; that observed temperature trends are due to natural causes, such as solar changes; or that the climate system will be resilient to the changes being observed. Conversely, Oppenheiemer etal (2007) caution that the climate change consensus may hide important feedbacks that could exacerbate warming effects, such as increased contribution from melting of glaciers upon sea level, and amplifying feedbacks between climate and carbon cycles (e.g. release of carbon from thawing permafrost); and possible interactions between sea surface temperatures and tropical circulation. Taken together, these arguments define a 'chain of uncertainty' that starts with predictions of future human activities, including energy scenarios and greenhouse gas emissions, to which is added variations in impacts on atmosphere composition, before introducing questions of scale, both temporal and spatial, over climate and hydrological responses.

Much of the climate change literature focuses where there is greatest consensus - on temperature, and precipitation. However, predicting flooding or drought hazards requires not only data on rainfall frequency and intensity but also for variables, such as evaporation, soil moisture and groundwater, which are much less commonly measured. This deficiency is particularly marked for evaporation. This is a key meteorological variable because it reflects the distribution of energy between sensible and latent heat fluxes, is required for predictions of soil moisture deficits which have implications for groundwater recharge and surface runoff, and is the basis for agroclimatological forecasts of food production. Measuring evaporation is complex, however (Smith, 2008), and recent reviews of methods for calculating potential evaporation for climate change studies (Kay and Davies, 2008; Kingston etal, 2009) note it may be an important source of uncertainty.

\section{The problem of downscaling}

The IPCC (2007) fourth assessment contains broad generalizations of future conditions but the literature identifies severe limitations for predicting localized and short term patterns of change. Some predictions, for example of future European drier summers and wetter winters, are fairly consistent. In contrast, for South Africa, predictions diverge, ranging from more days with heavy rain, changes in the number of consecutive rain days, through to no trend at all for annual total rainfall (Hulme ,1996; Kruger 2006). Others predict local spatial variations, with increased summer rainfall over central and eastern plateau (Drakensberg mountains) with little change in the Western Cape (Hewitson and Crane, 2006). This illustrates the uncertainty involved in interpreting results of regional Global Circulation Model (GCM) forecasts (for scale units of $100 \mathrm{~km}$ or more) to create local and catchment-scale hydrological forecasts. This was termed 'climate inversion' by Kim etal (1984) and recognized by the IPCC-TAR (2001) as 'downscaling'. Of the two methods commonly used, the statistical approach is faster but produced uncertain predictions for extremes of both precipitation and temperature than the more computationally demanding dynamic (synoptic) approach (Hundecha and Bardossy, 2008). Prudhomme etal (2002) believe that at present there is little confidence in precipitation predictions at time scales of less than a month, stating (p1139): "There exists no universal downscaling method for all situations", a view also supported by Hewitson and Crane (2006). The problem is not just one of choosing an appropriate method, as the statistical approach is dependent upon having a reliable data base to capture conditions. This presents problems for assessing the impacts of climate changes upon water resources, above all at a local level where they are 'visible' to the majority of people. 


\section{An unstable data base}

A further complication for climate analyses is that the actual networks of stations have changed during the observation period, creating the possibility of an added artifact in the climate signal (Chappell and Agnew 2008). In West Africa for example the number of stations decreased in the wetter coastal area while increasing in the drier continental area, while the total number of stations with complete records decreases dramatically after the late 1970s. The same observation was recently made for Africa as a whole and Kenya in particular at the $2^{\text {nd }}$ Africa Water Week in Johannesberg, "You can only get reliable rainfall data in Kenya up to 1980 as the existing infrastructure, like rain gauges and stream gauges, are no longer working," (SDN, 2009) . There are, then, a number of uncertainties from the basic observational networks through to predictions of global economic activity that need to be understood when giving advice on adaptation strategies. Given these uncertainties it can be understood why resilience - ability to withstand (unspecified) shocks - and adaptive capacity has become such an important concept.

\section{Technology and adaptation to climate change.}

As with water resource management, many of the initial steps in climate change adaptation have focused on technological change. Adaptation to water scarcity has focused infrastructure to secure supplies (Parry etal, 2009), or as Page (2008, p302) notes: "It is imperative that more capital should be fixed in the form of pipes, taps and reservoirs in the developing world". The wide range of available technologies (Agnew and Woodhouse, 2011), also address the priority of conserving water through more efficient use, including reducing pipe leakage that causes a 'normal' loss of between 10 and 20\% (Lahlou, 2001), or averaging $36 \%$ (within a range of 8 to $62 \%$ ) in Asia. While the problem of such water losses is mainly associated with urban areas, many rural irrigation systems have efficiencies well below $50 \%$. Heavily promoted water conservation measures include rainwater storage, water audits and water-efficient household appliances (Sharp, 2006), many of which may be 'retrofitted'. Deoreo etal (2001) noted that such measures in the USA enabled household consumption to be significantly reduced to around $150 \mathrm{lcd}$. Similarly, Kolokytha and Mylopoulos (2004) estimated a $20 \%$ decrease in consumption through residential retrofitting, while using grey water (e.g. rainwater) saved up to $39 \%$. The re-use of waste water is well established (Symons, 2006), with techniques suitable for water scarce regions and developing countries (Al Baz etal, 2008; Sanchez etal, 2006), including treatment of contaminated water through desalination (Burbano etal , 2007).

More strategic technological adaptation to climate change is evident in the concept of the 'adaptive city' (White, 2008) in which the design of urban areas can be used to adapt and even mitigate the expected increase in floods, while retaining water in the city can reduce scarcity. Similar goals inform 'green landscapes' in which water is conserved and temperatures are mitigated (Gill etal, 2007). Similar holistic approaches are evident in the use of rainfall water harvesting to improve resilience to water scarcity in Africa (Rockstrom, 2003). There are, then, many promising attempts to use technology to adapt to future climate extremes, but it is a challenge to introduce these ideas in congested impoverished areas of cities in the South. Therkildsen (1988) noted failed attempts in Africa to supply water in the 1960s and 1970s, and Thompson et al ( 2001) found in East Africa that mean water use had declined between 1960s to1990s due to reduced reliability of the piped water supply, as municipal water services could not maintain the infrastructure. As with our review of water resource infrastructure, at the beginning of this section, these failures mark the limits of engineering approaches, and responses have invariably highlighted a need for greater emphasis on economic, social and political aspects, such as the need for greater partnership with communities (Rietveld etal, 2008), management at the lowest appropriate level, community ownership of schemes, full cost recovery for operation and maintenance, recognizing key roles of women and inclusion of the poor (Gine and Perez-Foguet, 2008). These conclusions are consistent with DFID's (2001) lessons learned for water provision: 
recognise water as an economic good; respond to demand; put people at the centre. However, there is also evidence that such formulations may fall short of what is required. Examining failures in the supply of water in Mumbai, for example, Gandy observes that (2008, p122) an "array of technological, scientific and architectural innovations...enable wealthy households to insulate themselves from the environmental conditions of the poor", and concludes that "The recent history of Mumbai has militated against the kind of progressive political movements that galvanized processes in European cities during the second half of the $19^{\text {th }}$ century...".

We conclude, therefore, that while science and engineering lie at the heart of the ecological principle, and offer potential to deliver fresh impetus in adaptive behavior at a range of scales, these are unlikely to be successful in isolation from economic and political dimensions. This is illustrated by Integrated Water Resource Management (IWRM), a key application of the ecological principle. IWRM has been promoted widely (WWDR, 2006) as it enables different water users and different types of water to be managed within a single unit, normally the watershed defined by topography and surface hydrology (Lenton and Muller, 2009). Mollinga et al. (2007) argue that this hydrological catchment may impose a false boundary and that 'problemsheds' which are socio-political constructs are more appropriate as a unit of management, and hence regulatory organisation. The ecological principle, then, as with engineering-led adaptive strategies, may be imposing false boundaries that require people to 'fit' the data and institutional arrangements which are likely to be problematic. We now turn to economic and institutional dimensions of governance.

\section{Instrument Principle (economic instruments)}

We noted above that over the last 100 years financing of water management has changed in industrialized societies, from municipal to national scale and increasingly linked to strategic economic planning (Swyngedouw, 2006). Increasing scale has required greater investment and growing emphasis upon cost recovery, associated with intensifying contestation of how costs should be distributed. The need to raise investment from private sources and adoption of the instrument principle for water services and supply has moved the debate to whether water is a basic right or privately owned. The OECD (2003), for example, note that water can be regarded either as a 'public good' with everyone having a right to water in a noncompetitive manner, as a 'private good' that is owned and to which there are access restrictions, and a 'common good' to which there is non-competitive access only until the resource becomes scarce. It is argued that for adaptation to be successful, local resources will have to be harnessed alongside external injections of capital. The MDGs also recognize the need for adaptation to be based around economic and behaviour changes (Moriarty and Butterworth, 2003).

The $4^{\text {th }}$ World Water Forum, in Mexico City noted the necessity to develop local financing capacity and markets, concluding "This necessity is founded on the recognition that users and taxpayers are in the end the main financiers, and on the associated shift from full-cost recovery to a solidarity system of fair tariffs combined with targeted subsidies." (WWC, 2006: 108). This is echoed in UNESCO's World Water Development Report for 2009, published at the $5^{\text {th }}$ WWF in Istanbul, which states that in relation to financing: "while there may appear to be many financing options for water resources development, governments still have only three basic means of financing them: tariffs, taxes and transfers through aid and philanthropy." (WWDR, 2009: xxii). This makes clear the cost of borrowed capital, if it is not written off through international aid, must be paid by users or by taxes. Here is a perspective in which the 'instrument principle' remains - in that access to water is defined as having a cost - but that the social distribution of that cost is governed by social criteria of need and 
ability to pay. The same debate will need to take place over interventions concerning climate change adaptation.

One of the key financial mechanisms to raise revenues has been water pricing. However pricing is also proposed as a means of adapting to greater scarcity through its inclusion in Water Demand Management (WDM), which has become an key strategy across the world including Europe (Sharp,2006), the Middle East (Magiera etal, 2006) and China (Chen etal,2005). WDM contains three elements that are reflected in adaptation strategies to climate change, economic (water pricing); technical (Infrastructure, including metering, recycling and retrofitting); and social (education, legislation and regulation). Most attention has focused on a range of socio-economic strategies that seek to influence water demand (Babel etal 2007). Kolokytha and Mylopoulos (2004: 263) are emphatic about the need for a change in direction, "demand management is considered to be the best potential solution to meet future (water) needs" because, they argue, supply enhancement does not effectively deal with growing competition between consumers. Treating water as a commodity rather than a basic human right is not without criticism, and many factors can influence responses to water prices (Martinez-Espineira, 2002, Jeffrey and Geary, 2005 and Kenney etal, 2008). Renzetti (2002:157 \& p158) conclude, "In general, the demand for water is a function of its price, the prices for other goods, the scale of activity... and the nature of the preferences or technology of the decision maker.....except in very unusual circumstances, the value of water is neither zero nor infinite" but they note that economic theory does not provide guidance on the actual decision making by the consumer. Sharp (2006) echoes this perspective and criticises previous studies of demand management for their aggregation of data hence failing to understand household decisions sufficiently. Jansen and Schulz (2006) note a lack of micro level studies, and cite a household study from Sri Lanka which showed demand was actually price-inelastic and income-inelastic, so price increases may not conserve water. Their study of demand in South Africa similarly found that low income groups' water use showed only modest responses to change in prices, while cheap water for poorer groups did not lead to greater wastage.

The South African case is of particular interest because the 1997 Water Services Act explicitly recognised a 'right of access to basic water supply and sanitation' of 25 Icd, funded in a variety of ways. In urban municipalities with substantial income from metered water users, a rising block tariff recouped the cost of the initial 'free' water, while rural water supply was capped at a 'free basic' level by 'appropriate service levels' provided through standpipes with restricted flow rates. It is relevant that there is a history of non-payment for services in South Africa, although Brown's (2005) study in Nelspruit led her to argue that a culture of non-payment is not simply a legacy of historic rates boycotts, though this is still within living memory. Rather, it is made up of many contributing factors which have resulted in an environment where it is the norm not to pay service bills, regardless of ability to pay. This highlights the importance of legitimacy in determining the viability of pricing policy. The association of pricing policies with a transfer of ownership (privatization) has significantly undermined legitimacy in some cases. Less than $5 \%$ of the world's population are supplied water by the private sector (Anand, 2007), and it is important to note that privatisation is not necessary for the operation of a pricing system for water. Anand (2007) notes the notion of fairness is paramount in attitudes to privatisation and whether water should be treated as a public good. That is, how much people trust the government to ensure everyone is treated in a similar manner, may explain why privatisation in England and Wales was accepted while in India, Tanzania or Ghana it produced protests (Anand, 2007).

Turning from investing in water to funding responses to climate change adaptation and mitigation we find the sums required are staggering. Drought is often cited as the world's costliest natural disaster, causing annual damage worth US\$6 to $\$ 8$ billion (Wilhite 2000). During the UN Drinking Water Supply and Sanitation Decade (1981-90) a total of US\$13.5 billion was invested (Tebbutt, 1998, p259), and at that time it was estimated future 
investment in water supply and sanitation would have to increase five fold to US $\$ 5$ billion a year. All this is dwarfed, however, by the sums required to tackle climate changes. The Stern report (2006) predicted climate change impacts would cost 5 to 20\% global GDP whereas mitigation costs would be less than 1\% GDP if acted upon now. The IWA Vienna Conference (Jowit, 2008) reported that World Bank investment to combat climate change would need to more than double the current annual rate of $\$ 80$ billion, just to cope with the current situation through mitigation and adaptation. Parry etal (2009) have noted a convergence of predictions of the expected costs of adaptation for developing countries with figures falling between US\$10 to 100 billion per annum (p9) "The UNFCCC report concluded that total funding need for adaptation by 2030 could amount to $\$ 49-171$ billion per annum globally, of which $\$ 27$ - 66 billion would be needed (mostly for infrastructure) in developing countries". Unfortunately Parry etal also concluded that the UNFCCC forecasts may be a two to three fold underestimate. Dimitrov (2010:815) reports that the (2009) Copenhagen Accord contains a commitment to additional funding for mitigation and adaptation of US\$30billion for 2010-12, rising to US $\$ 100$ billion by 2020 from public and private sources, but notes this is nonbinding and does not provide details on institutional arrangements.

This is not just a problem of funding adaptation for the rural poor. Since 2008 some 3.3. billion people are estimated to be living in urban areas, which is expected to rise to 5 billion by 2030 . Much of this growth is taking place in Africa and Asia, so that by $203081 \%$ of the urban population will be in developing countries. We note here again, the caveat that such estimates may overestimate urban growth rates (Potts, 2009) but existing numbers of urban poor means that many now live in squalor with limited ability to respond to climate changes, (Bicknell etal , 2009; Moser and Satterthwaite, 2008). DeBruijne etal (2007) note that in many respects the situation facing urban areas in the south is far worse than for Europe 150 years ago. Poverty is deeper, there are fewer opportunities to access land and water resources, and existing resources are being degraded through pollution and over-abstraction.

Responding to climate change includes a combination of market-based mechanisms along side technology transfer and human lifestyle changes (Dessler and Parson 2006), but investment is required. The key question is: who should pay? We have already presented a growing emphasis upon cost recovery for water resources investment moving from state intervention to private capital. Swyngedouw (2006), notes that much of the investment required to meet the water Millenium Development Goals is expected from the private sector and this is reinforced in a recent UN analysis (Griffith-Jones etal, 2009). Discussion of climate change mitigation focuses upon the need to recognize the responsibility (both current and historic) of the high emissions from the industrialized nations while costs of impacts fall upon the most vulnerable and poorest communities found in the south. The Stern report was a major contribution to the argument that the global cost of immediate action to mitigate climate change outweighed the eventual cost of dealing with climate change impacts. However, the size of the costs involved have arguably only served to intensify argument over who should pay. There is also controversy over the effectiveness of the economic tools available for mitigation, and the potential conflict between mitigation and economic growth (Cosbey, 2009), but the major problem is the expected cost of sharing the burden. Ahmad and Opschoor (2009) note there is currently limited funding, especially for current adaptation measures never mind those extending well into the future: 'Given the nature of adaptive capacity and its linkage with development in general, strategizing development planning and raising development finance is essential in meeting adaptation requirements.'

We are, then, at an interesting turning point in the management of climate change impacts where the need to raise capital for investment and the adoption of economic principles for management have promoted private, non-state engagement. Similar moves in the management of water resources two decades earlier have been followed by promotion of greater public engagement, for example in the EU (2000) Water Framework Directive (Carter, 2007). Dungumaro (2007) cites public participation as a core of Integrated Water 
Resources Management. Hence questions of governance and stakeholder involvement have come to the fore as illustrated in figure 1 . We will expand upon these next, not least because it has become clear that economic tools need to be informed by detailed political understanding of how behaviour can and will be changed.

\section{Institutional principle (participatory decision making)}

By the 1970s the effectiveness of state-led 'top down' development was being questioned and two alternatives proposed. One, which we discussed above, sought to make resource allocation decisions subject to the 'discipline' of markets as understood in classical economics. The second, associated with Jurgen Habermas, promoted ideas of a more active 'participatory' citizenship, with decisions being subjected to 'deliberative democracy' in which technical experts would be engaged in discussion by ordinary 'lay' citizens to examine the rationale and consequences of new developments. In this section we consider increased participation in adaptation strategies which can broadly be seen through raising awareness, stakeholder engagement, and upscaling and dissemination.

Efforts to involve people as 'stakeholders' in planning activities have been fostered by many reforms to water management institutions and by efforts to use spatial planning (Howe and White, 2004) to contribute to sustainable development. Carter (2007) argues that spatial planning has become a key discipline promoting participatory measures, the benefits being increasing democratic legitimacy, building consensus and strengthening decision making. Equally, some countries, such as South Africa (Brown, 2007) and the EU (Carter, 2007), have incorporated stakeholder participation in water development policy. Developing experience in implementing such initiatives has seen the concept of 'social learning' come to the fore, described by Van Slobbe etal (2008) as a move away from linear planning and emphasis upon expert knowledge. Blackmore etal (2004:6) explain social learning to mean, "a process of knowing based upon experience and practice that is developed collectively and interactively among multiple interdependent stakeholders".

Increased participation needs to recognise the importance of gender which was included in the institutional principle and incorporated into MDG3. The UNDP's (2010) web site for women's empowerment (http://www.undp.org/women/) states forcibly that "Development cannot be achieved if 50 percent of the population are excluded". In the past, water resources development assumed that households would alter their practices in a predictable manner to take advantage of improvements in water supply. Such assumptions have been criticized for failing to take adequate account of intra-household decision-making and the gendered outcomes of changing natural resource management (Nyong and Kanaroglou, 2001; Hunter, 2006), including cultural restrictions placed on women moving from private (household) spaces and into the public realm, (Sultana,2009). In urban areas constraints still exist, although space may be constructed differently and women in urban households may have greater access to assets (Moser and Dani, 2008). Efforts to overcome gendered constraints to participation are reinforced by research identifying more positive roles of women in water management (Wirfa etal, 2008; Fonjong,2008; Were etal, 2008).)

An appreciation of the importance of stakeholder participation has been associated with a reinterpretation of the reasons for the failure of water pricing to deliver expected changes. In particular a reappraisal of the role of 'communication', sometimes referred to as 'education', has identified the danger that this becomes top-down, reinforcing the position of the 'expert'. As Page $(2008,298)$ observes "The engineers and politicians who now manage water supplies in Cameroon claim that most consumers are reluctant to pay for their water because they are ignorant; their attitudes need to be modified." The messages from water companies 
through web sites and leaflets plus occasional media campaign (e.g. during droughts) are criticised as being ineffective in changing behaviour (Sharp,2006; Kenny etal, 2008). Conversely, Fenemor etal (2008) studied community resilience in New Zealand through developing active partnerships involving the knowledge base of resource users, and stakeholder involvement in management. It appears to be important that conversations are initiated as early as possible so that both agendas and language are shared. Lundqvist, (2000) also notes the significance of water user engagement alongside the need for better training and human capacity building: (p264) "Education, training and research must transcend borders, between disciplines and between sectors and between cultures and countries".

Blackmore etal (2004) concluded that obstacles to stakeholder participation in water resources development include overly complex institutional contexts and lack of experience with this strategy. Van Slobbe etal (2008) note how in Sri Lanka there has been frustration over 'too much' participatory engagement, and concluded participatory practices require investment of time for interactions and negotiation, and social spaces for this to take place, and there is a need for patience and tolerance as results are not instantaneous. Brown (2007) has also cautioned about the limitations that participatory approaches may offer in practice, and the frequent absence of evaluation of the outcome of stakeholder involvement. Her study in South Africa suggested that, where stakeholders have strongly competing interests in water use and where there are major asymmetries in information, it is unlikely that consensus will be reached through consultation among 'local stakeholders'. Another South African study (Brown, 2009) broadly supports this conclusion but also raises questions as to whether 'social learning' raises too many expectations with regard to stakeholders' collective interest in collaborative management being greater than their individual (and potentially competing) benefits from non-collective water use.

A persistent challenge to initiative seeking to develop more effective stakeholder engagement in adaptive water resource management is the "upscaling" of participation by single individuals to the level of communities. A similar step may be needed to enable collective management of the impacts of climate change. Ryan (2004) notes that adaptation is constrained by poverty due to limited resources (funds, human capital, institutional capacity), lack of knowledge or shared understanding and resistance to change. Communitydriven approaches such as Community Led Total Sanitation (CLTS), offer some promise of improvements (Deak, 2008), but there is no consensus over the best approach to scaling up adaptive action from individuals and households, either spatially or vertically (institutions and social hierachy). Ryan's (2004) review of the literature on upscaling underlines a lack of rigour in defining project objectives and an over-emphasis upon anecdotal reporting of project achievements. The review describes the following key roles for different stakeholders:

- Local Community: managing the process and in control.

- Central Government: institutional support through financial and legal provision.

- NGOs: facilitation, support and training.

- INGOs: advocacy and support.

- Private Sector: supply chain development.

- International Community: long term commitment without intervention.

Large disparities in socio-economic conditions present problems for the consistent engagement of stakeholders across a water catchment. In South Africa, Brown (2007) found that stakeholder preferences varied so greatly within studied catchments that it blocked consensus and effective decision-making. More positive experiences in Bangladesh on Community Led Total Sanitation projects have spread and Deak (2008) notes here the importance of 'self spread', promoted through enthusiastic champions. Other critical factors identified included: planning that assessed coverage (spatial) together with sustainability 
(timescale); institutions, partnerships and policy support for community engagement; capacity building and financial stability; and a shift from 'project implementation' to 'service delivery'. We have, then, identified from the water development literature a number of obstacles to greater subsidiarity and devolved decision making from questions of scale through to the need for social learning and capacity building. There is strong advice that for technical and scientific support to be fully effective there needs to be engagement with stakeholders at the earliest opportunity while consultation must be more than simply seeking responses to written reports.

Strategies of greater engagement with stakeholders have also gained strong support in discussions of climate change adaptation, promoted by the IPCC (2001) through the notion of a community's adaptive capacity. Similar ideas at household scale have sought to estimate vulnerability in terms of household assets and capital which are identified as key components of an ability to make environmental responses to climate change (Nicol, 2000; de Graaf, 2007). This emphasis upon household adaptive capacity is also found in Wamsler's (2007) analysis of disaster risk reduction in El Salvador. She lists three types of coping strategies: reducing risks (through technical measures (e.g. construction), environmental controls (e.g. runoff reduction), economic measures (e.g. diversifying income) and organizational change (e.g. social networks); insuring against risks through self insurance e.g. education, ownership and family or institutional insurance (e.g. community engagement); and, finally, recovering from risks (through loss financing and community action). A similar approach is evident in a recent change in attitude to flood risk management in the UK (Johnson et al, 2007), moving from a purely engineering approach of flood defence measures to management of risks in much the same way as noted by Pereira (2007), for drought management. Rather than seeing nature as something to be controlled and dominated, the new attitude places more emphasis upon adaptation that ensures ecological integrity: 'living with floods.'

In Pelling's (2011) review of adaptive management, he argues the concept emerged three decades ago to support decision making under conditions of uncertainty, with an emphasis upon social learning. He goes onto argue adaptive management has a role to play in adaptation to climate change, where there is much uncertainty and a need for multistakeholder engagement for social learning. However, he cautions (p32) that, to be effective, institutions and organizations need to be receptive to local viewpoints, for sustaining local engagement is a challenge, and for community- led efforts to be credible they need to secure technical and scientific support. The last point nicely returns us to the first principle and emphasizes that at no time do we suggest that the three principles are implemented in isolation, rather it is a matter of emphasis.

\section{Conclusions}

In this paper we have explored the growing consensus on water development strategies based upon three principles: ecological, 'instrument' (economic) and institutional. We have argued that the same consensus is required for climate change responses, in particular to embrace the institutional principle with an emphasis upon governance and stakeholder engagement while noting the significance of the instrument principle, that is, that investments need to be financed in an equitable and legitimate manner. However, recent efforts to implement the institutional principle, which fosters subsidiarity and the engagement of people and communities in water governance, has not been without difficulties. It does not offer a panacea. We have reached the same conclusion for strategies which are science or economically focused. 
Tackling environmental constraints through science and technology (e.g. by increasing the supply of water, or by conservation measures to maintain ecosystem functions). These can have major impacts, for example through large dams, but raise problems over the distribution of benefits, and the subordination of individual or local community interests to a 'greater common good'. We have argued that science and technology is necessary, but insufficient, on its own, to foster adaptive capacity, since it does not provide the means with which to manage uncertainty, both inherent in scientific measurement and arising from economic and social factors. If science therefore does not hold all the answers, so the (Weberian) scientific arguments based on a 'greater common (public) good' may not find acceptance,

Two alternative, and opposing views have gained importance as the efficacy of science has been questioned:

Neoliberal: pricing to ensure efficient resource use. Understanding the costs associated with resource use is a necessary dimension of adaptive capacity, but considerations of economic efficiency will be conditioned by questions of equity (distribution of costs and benefits) and, linked to this, political perceptions of fairness (e.g. whether some people have unmet needs that may be regarded as 'human rights') and legitimacy.

Institutional: deliberative and accountable democracy to decide who gets allocated what. This rests on a belief in the power of rational argument to ensure adaptive behaviour is equitable and politically legitimate, but is undermined by asymmetric power relations, by which more powerful stakeholders prevail over others, irrespective of questions of equitable resource use. A key aspect of such asymmetries of power is an asymmetry in access to information, and particularly to scientific information and understanding of environmental processes and change.

This prompts a need to re-evaluate the role of the state and the political processes through which development goals and priorities are determined and implemented.

A set of parallel, but more recent discussions, have developed concerning adaptation to climate change. Science has arguably led the discussion and has dominated policy formulation, but is beset with uncertainty especially at the local scale where adaptation will have to take place. Technology will be important for various forms of adaptation, from water conservation measures through to flood storage engineering or water supply enhancement, but it has to be paid for. The sums involved globally are staggering and this has moved us increasingly into discussions of investment in mitigation and financial support to developing countries for adaptation measures. The experience of carbon trading, tradable emissions quotas etc. suggests, however, that wider issues of ownership and equity need to be addressed alongside the capacity for private investment. In practice, the lack of binding commitments from Copenhagen (2009) has highlighted the problems of adopting the instrument principle to combat climate change: as with water resources, the lack of funds in many parts of the world most at need means that adaptation will need to rely heavily upon social and political organisation. In addition, the lessons from nearly half a decade of water pricing and demand management is that people do not always respond in a predictable manner to economic measures.

This has contributed to more recent emphasis upon governance, including community based actions and social learning, to meet the challenges presented by climate change. The experiences of water development however are not entirely promising, and have exposed the limitations of local participation in bringing about change, particularly where asymmetries of power and conflicts of interest will tend to translate into competition to control scientific information and its interpretation. Reliance on local decision-making has proved difficult not only because of the asymmetries of power, but also because of the need for up-scaling. We will then find all three principles advocated with different degrees of emphasis to support 
adaptation measures, but assessing which is most appropriate becomes a question of the purpose of the adaptation. Is it a short term response to an immediate threat or are the measures intended to support the community long term through fundamental changes in lifestyle and land use? As with adaptive management of water resources, the question essentially requires the development goals of climate change adaptation to be agreed, for it is only against these that measures to adapt to climate change can be effectively evaluated.

\section{References (websites verified January 2010 unless otherwise stated)}

Agnew,C.T. 2002 Drought, desertification and desiccation; the need for further analysis. Geography Journal 87(3):256-267

Agnew,C.T. and Woodhouse,P. 2011 Water Resources and Development. Routledge, London.

Ahmad,I.H. and Opschoor,J.B. 2009 Reaching a climate deal in Copenhagen. UN-DESA Policy Brief No 17. Department of Economic and Social Affairs, New York

Al-Baz ,I. Otterphohl,R. and Wendland,C. eds. 2008 Efficient Management of wastewater, Springer-Verlag, Berlin.

Anand, P. (2007) Scarcity, Entitlements and the Economics of Water in Developing Countries. Edward Elgar

Anderson,K. \& Bows.A. 2008 Reframing the climate change challenge in the light of post2000 emission trends. Philosophical Transactions of the Royal Society A 366:3863-3882

Arnell,N.W. 2002 Hydrology and Global environmental change. Pearson, Harlow.

Arnell,N.W. 2003 Relative effects of multi-decadal climatic variability and changes in the mean and variability of climate due to global warming: future stream flows in Britain. Journal of Hydrology 270:195-213

Arnfield,A.J. 2003 Two decades of urban climate research: a review of turbulence, exchanges of energy and water, and the urban heat island. International Journal of Climatology 23:1-26 DOI: 10.1002/joc.859

Altinbilek,D. 2002 The role of dams in development. Water Resources Development 18(1) 924.

Babel,M.S., Das Gupta,A. and Pradhan,p. 2007 Water Resource Management 21:573-589.

Bandyopadhyay, J. 2002 A critical look at the report of the World Commission on Dams in the context of the debate on large dams on the Himalayan rivers. Water Resources Development 18(1): 127-45

Bell, V.A. Kay, A.L. Jones,R.G. and R. J. Moore 2007 Use of a grid-based hydrological model and regional climate model outputs to assess changing flood risk International Journal of Climatology 27(12): 1657-1671

Bicknell, J., Dodman, D. and Satterthwaite, D. (eds) (2009) Adapting Cities to Climate Change, London: Earthscan 
Bird, J. 2002 Nine months after the launch of the World Commission on Dams Report. Water Resources Development 18(1): 111-26

Blackmore,C., Collins,K., Furniss,P., Morris,D. and Reynolds,M. 2004 The UK policy context for water management. I - the English and Welsh policy context. SLIM case study monograph 12A. The Open University. http://slim.open.ac.uk

Brown,J. 2005 Water Services and the Poor: A Case Study of the Greater Nelspruit Utility Company, Mbombela Municipality, South Africa. CRC Working Paper 12[1]. (http://www.competition-regulation.org.uk/publications/working_papers/).

Brown,J. 2007 Participatory Processes and Outcomes of South Africa's Water Reforms. PhD Thesis, School of Environment and Development, University of Manchester.

Brown, H. 2009 Social Learning within participatory, catchment-based water management processes in South Africa and Namibia. PhD Thesis, University of Sheffield, UK

Burbano,A.A, Adham,S.S. and Pearce,W.R. 2007 The state of full scale RO/NF desalination. The results of a worldwide survey. American Water Works Association. Journal 99(4): 116-127

Carter,J. 2007 Spatial planning, water and the Water Framework Directive: insights from theory and practice. The Geogaphical Journal 173(4): 330-42

CAWMA 2007 Comprehensive assessment of water management in agriculture. Colombo/London: International Water Management Institute and Earthscan.

CDWR 2009 California Drought: an update, June 2009. California Department of Water Resources. Sacramento. http://www.water.ca.gov/drought/docs/Drought_report_30june2009_web.pdf

Challinor,A.J., Ewert,F., Arnold,S., Simelton,E., and Fraser,E.2009 Crops and climate change: progress, trends, and challenges in simulating impacts and informing adaptation. J. Exp. Bot. 60, 2775-2789

Chambers, R. 1994 The origins and practice of participatory rural appraisal

World Development 22(7): 953-69

Chappell, A. and Agnew, C. 2008. How certain is desiccation in west African Sahelrainfall (1930-1990)? Journal of Geophysical Research-Atmospheres Vol 113 D07111, doi:10.1029/2007JD009233

Chen,Y. Zhang,D., Sun,Y., Liu,X., Wang,N. and Savenije,H.G. 2005 Water demand management: a case study of the Heihe River Basin in China. Physics and Chemistry of the Earth 30(6-7):408-419

Christman,K. 1998 The history of chlorine . accessed at, Water Quality and health http://www.waterandhealth.org/drinkingwater/history.html

Cosbey,A. 2009 Developing country interests in climate change action and the implications for a post-2012 climate change regime. UN Conference on Trade and Development UNCTAD/DITC/BCC/2009/2 New York. 
Deak,A. 2008 Taking community led total sanitation to scale: movement, spread and adaptation. IDS Working Paper 298., University of Sussex.

De Bruijne, G., Geurts, M and Appleton, B. 2007 Sanitation for all ? IRC International Water and Sanitation Centre (www.irc.nl).

deGraaf,R. van Giesen,N. and van de Ven,F. 2007 Alternative water management options to reduce vulnerability for climate change in the Netherlands. Journal of the International Society for the Prevention and Mitigation of Natural Hazards (on line 10.1007/s11069007-9184-4 ) 17pp.

Deoreo,W.D., Dietemann,A., Skeel,T. and Mayer,P.W. 2001Retrofit realities. American Water Works Association. Journal 93(3): 58-72

Dessler,A.E. and Parson, E.A. 2006, The science and politics of global climate change : a guide to the debate. CUP, Cambridge.

DfID 2001 Addressing theWater Crisis: healthier and more productive lives for poor people. UK Department for International Development. www.dfid.gov.uk/Documents/publications/tspwater.pdf

Dimitrov,R.S. 2010 Inside UN climate change negotiations: The Copenhagen conference. Review of Policy Research 27(6):795-821.

Dow, K. and Downing, T. 2006 The Atlas of Climate Change: Mapping the World's Greatest Challenge. Earthscan, London

Dungumaro,E.W. 2007 Socioeconomic differnatials and availability of domestic water in South Africa. Physics and Chemistry of the Earth 32:1141-1147.

FAO-AQUSTAT (2009) Food and Agricultural Organisation, UN. AQUASTAT http://www.fao.org/nr/water/aquastat/regions/

Fenemor,A. , Deans,N., Davie,T., Allen,W., Dymond,J., Kilvington,M., Phillips,C., Basher,L., Gillespie,P., Yong,R., Sinner,J., Harmsowrth,G., Atkinson,M., \& Smith,R. 2009 Collaboration and modelling- Tools for integration in the Motueka catchment, New Zealand. Water South Africa 34(4):448-455.

Fonjong, L. N.2008 Gender Roles and practices in natural resource management in the North West Province of Cameroon. Local Environment, 13: 5, 461 - 475

Franke F. and Chasin B., 1980: Seeds of Famine. Allanheld, Osman and Co., New Jersey.

Gandy, M. 2008 Landscapes of Disaster: water, modernity, and urban fragmentation in Mumbai Environment and Planning A 40: 108-130

Ganoulis,J. Skoulikaris,H. Monget,J.M. 2008 Involving stakeholders in transboundary water resources management: the Mesta/Nestos HELP basin. Water South Africa 34(4):461-67

Gill, S., Handley, J.F., Ennos, R., and Pauleit, S., 2007, Adapting cities for climate change: the role of green intrastructure. Built Environment, 33(1), 97-115.

Gine,R. and Perez-Foguet,A. 2008 Sustainability assessment of nbational rural water supply program in Tanzania. Natural Resources Forum 32: 327-342 
Glantz,M.H. 1994 Drought follows the plow, cultivating marginal areas. CUP, Cambridge.

Goldsmith, E. and Hildyard, N. (eds) 1984 The Social and Environmental Effects of Large Dams, Vol. 1, Case Studies, Wadebridge Ecological Centre, Cornwall

Guardian 2009 Copenhagen closes with weak deal that poor threaten to reject, 19/12/2009 http://www.guardian.co.uk/environment/2009/dec/19/copenhagen-closes-weak-deal

Gregory, J. M., and J. A. Lowe (2000), Predictions of global and regional sea-level rise using AOGCMs with and without flux adjustment, Geophysical Research Letters 27(19): 30693072.

Griffith-Jones,S., Hedger,M. and Stokes,L. 2009 The role of private investment in cinreasing climate friendly technologies in developing countries. UN-DESA. New York.

HDR 2006 Beyond Scarcity Human Development Report 2006. New York: United Nations Development Programme.

Hewitson,B.C. and Crane,R.G. 2006 Consensus between GCM climate change projections with empirical downscaling: precipitation downscaling over South Africa. International Journal of Climatology 26:1315-1337

Holling,C.S. 1973 Resilience and stability of ecological systems. Annual Review of Ecology and Systematics. $4: 1-23$.

Howard,G. and Bartram,J. 2003 Domestic Water Quantity, Service Level and Health WHO Report WHO/SDE/WSH/03.02 WHO, Geneva http://www.who.int/water_sanitation_health/diseases/WSH03.02.pdf

Howe,J. and White,I. 2004 The mismanagement of surface water. Applied Geography 24: 261-80

Hulme, M. 1996 Climate change and Southern Africa: an exploration of some potential impacts and implications in the SADC region. Climatic Research Unit, UEA and WWF International.

Hulme,M. 2009 The science and politics of climate change. The Wall Street Journal $2 / 12 / 2009$

Hundecha,Y. and Bardossy,A. 2008 Statistical downscling of extremes of daily precipitation and temperature and construction of their future scenarios. International Journal of Climatology 28(5): 589-610

Hunter,L. 2006 Household strategies in the face of resource scarcity

in coastal Ghana: are they associated with development priorities? Population Resources Policy Review 25:157-174

IPCC 1990 First Assessment Report. Intergovernmental Panel on Climate change, Geneva.

IPCC 1995 Second Assessment Report: Climate change. Intergovernmental Panel on Climate change, Geneva.

IPCC 2001 Third Assessment Report: Climate change. Intergovernmental Panel on Climate change, Geneva. http://www.ipcc.ch/ipccreports/tar/vol4/index.php?idp=0 
IPCC 2007 Fourth Assessment on climate change. IPCC, Geneva. Climate change synthesis report. Intergovernmental Panel on Climate change, Geneva.

http://www.ipcc.ch/publications and data/publications ipcc fourth assessment report s ynthesis report.htm

IPCC 2008 Fourth Assessment on Climate Change. IPCC, Geneva.

http://www.ipcc.ch/publications_and_data/publications_ipcc_fourth_assessment_report_s ynthesis_report.htm

Jansen, A. and Schulz, C. 2006 Water demand and the urban poor: a study of the factors infl uencing water consumption among households in Cape Town, South Africa. South African Journal of Economics 74(3): 593-609

Jeffrey, P. and Geary, P. 2005 Consumer reactions to water conservation policy instruments. In Butler, D. and Memon, F.A. (eds) Water Demand Management. IWA, London. pp. 305-30

Johnson,C. Penning-Rowsell,E. and Parker,D. 2007 Natural and imposed injustices: thje challenges in implementing fair flood risk management policy in England. The Geographical Journal 173(4): 374-90

Jowit 2008 Environment: Huge increase in spending on water urged to avert global catastrophe Guardian 11/9/2008.

http://www.guardian.co.uk/environment/2008/sep/11/water.climatechange

Kay,A.L. \& Davies,H.N. 2008 Calculating potential evaporation from climate model data: a source of uncertainty for hydrological climate change impacts. Journal of Hydrology 358:221-229

Kenny,D.S., Goemans,C., Klein,R., Lowrey,J. and Reidy,K. 2008 Residential water demand management: Lessons from Aurora, Colorado. Journal American Water Resources Association 44(1):192-207.

Kerr,R.A. 2007 Global warning is changing the world Science 316: 188-90.

Kim, J.-W., Chang, J.-T., Baker, N.L., Wilks, D.S. and Gates, W.L. 1984 The statistical problem of climate inversion: determination of the relationship between local and large scale climate. American Meteorological Society, Monthly Weather Review 112: 2069-77

Kingston,D.G., Todd,M.C., Taylor,R.G., Thompson,J.R. \& Arnell,N.W. 2009 Uncertainty in estimates of potential evapotranspiration under climate change. Geophysical Research Letters 36 doi10.1029/2009GL040267

Kolokytha,E.G. and Mylopoulos,N.A. 2004 Evaluating demand management aspects of urban water policy. The city of Volos Case, Greece. Water, Air and Soil Pollution 4:263277.

Kruger,A.C. 2006 Observed trends in daily precipitation indices in South Africa: 1910-2004. International Journal of Climatology 26:2275-2285

Lahlou,Z.M. 2001 Leak detection and water loss control. Technical Brief: National Drinking Water Clearinghouse Fact Sheet (May) $5 p$. 
Lemos,M.C. 2003 A tale of two policies: the politics of climate forecasting and drought relief in Ceara, Brazil. Policy Sciences 36(2):101-123

Lenton, R. and Muller, M. 2009 Integrated Water Resources Management in Practice. Earthscan, London

Lloyyd-Hughes,B. and Saunders,M.A. 2002 A drought climatology for Europe. International Jounral of Climatology 22:1571-1592.

Lundqvist,J. 2000 A Global Perspective on Water and the Environment. Physics and Chemistry of the Earth 25(3): 259-264.

Maddaus,M.L. ,Maddaus,W., Torre,M. and Harris,R. 2008 Innovative water conservation supports sustainable housing development American Water Works Association. Journal 100(5):105-110

Magiera,P, Taha,S. and Nolte,L. 2006 Water demand management in the Middle East and North Africa Management of Environmental Quality 17(3):289 - 298

Maier,H., Jain,A. Dandy,G.C. \& Sudheer,K.P. 2010 Methods used for the development of neural networks for the prediction of water resource variables in riover systems: current status and future directions. Environmental Modelling and Software 25:891-909

Marsalek,J, Jimenez-Cisneros,B.E., Malmquist,P.A., Karamouz,M., Goldenfum,J. and Chocat,B. 2006 Urban water cycle processes and interactions. International Hydrological Programme Technical Documents in Hydrology No 78. UNESCO, Paris.

Martinez-Espineira,R. 2002 Residential water demand in northwest Spain. Environmental and Resource Economics 21:161-187.

McGuire,M.J. 2006 Eight revolutions in the history of UD drinking water disinfection. Journal of American Water Works Association 98(3): 123-149

MDG 2000 United Nations Millenium Development Goals. http://www.undp.org/mdg/basics.shtml).

Meir,M.F. Dyurgerov,M.B. Rick,U.K. O'Neel,S. Pfeffer,W.T. Anderson,R.S. Anderson,S.P. Glazovsky,A. 2007 Glaciers dominate eustatic sea level rise in $21^{\text {st }}$ Century. Science 317: 1064-67.

Meteorological Office (UK) 2010 Climate change. http://www.metoffice.gov.uk/climatechange/

Mollinga, P.P., Meinzen-Dick, R.S. and Merrey, D.J. 2007 Politics, pluarality and problemsheds: A strategic approach for reform of agricultural water resources management. Development Policy Review 25(6): 699-719

Moriarty,P. and Butterworth,J. 2003 The productive use of domestic water supplies. IRC International Water and Sanitation Centre (www.irc.nl)

Moser, C. and Dani,A. (eds) (2008) Livelihoods, Assets and Social Policy, Washington DC, World Bank. 
Moser,C. and Satterthwaite,D. 2008 Towards pro-poor adaptation to climate change in the urban centres of low and middle income countries. International Institute for Environment and Development, London.

Nature 2006 A scramble for Africa: Large dams benefi t contractors and corrupt governments more than they aid the African people (Editorial). Nature 440: 383-84

New Scientist 2008 China's dams in the danger zone (Editorial). New Scientist 2659 (4 June )

Nicol, A. (2000) 'Adopting a Sustainable Livelihoods Approach to Water projects: Implications for Policy and Practice', Working Paper, No. 133, London: Overseas Development Institute (ODI).

Nyong,A.O. and Kanaroglou,P.S. 2001 A survey of household domestic water-use patterns in rural semi-arid Nigeria. Journal of Arid Environments 49: 387-400

OECD 2003 Social Issues in the Provision and Pricing of Water Services. Organisation for Economic Cooperationand Development. OECD Publishing, Paris.

OFWAT 2007 UK Water Services Regulation Authority, Household water consumption for 2007 (accessed January 2010) http://www.ofwat.gov.uk/

Oldfield,F. 2005 Environmental change: key issues and alternative approaches. Cambridge University Press, New York.

Oppenheimer,M. O'Neill,B.C. Webster,M. and Agrawala,S. 2007 Climate change: The limits of consensus. Science 317: 1505-6

Ortolano, L. and Cushing, K.K. 2002 Grand Coulee dam 70 years later, what can we learn ? Water Resources Development 18(3): 373-90

Page,B. 2005 Paying for water and the geography of commodities. Trans. Inst. British Geographers 30:293-306

Parry,M., Arnell,N.,Berry,P.,Dodman,D.,Fankhauser,S. Hope,C., Kovats,S.,Nicholls,R., Satterthwaite,D. , Tiffin,R. and Wheeler,T. 2009 Assessing the costs of adaptation to climate change. A review of the UNFCCC and other recent estimates. IIED, London.

Parry,M. Rosenzweig,C. and Livermore,M. 2005 Climate change, global food supply and risk of hunger. Phil. Transactions Royal Soc. B. 260:2125-2138

Pearce,F. 2006 Mega-dams back on the agenda. New Scientist 191(2569): 10

Pelling,M. 2011 Adaptation to climate change. From resilience to transformation. Routledge, London.

Pereira,L.S. 2007 Drought impacts in agriculture: water conservation and water saving practices and management. Chapter 17 in Rossi,G. etal Methods and tools for drought analysis and management, Springer-Verlag, Berlin. 349-73

Peter,G. 2006 Gender roles and relationships: Implications for water management Physics and Chemistry of the Earth 31: 723-730 
Plummer,J. \& Slaymaker,T. 2007 Rethinking governance in water services. ODI Working Paper 284. Overseas Development Institute, London.

Ponte,L. 1976 The cooling. Prentice-Hall, New Jersey.

Postel, S. 1992 The Last Oasis, Facing Water Scarcity. Earthscan, London

Potts,D. 2009 The slowing of sub-saharan Africa's urbanization: evidence and implications for urban livelihoods. Environment and Urbanization 21(1): 253-259

Prudhomme,C., Reynard,N. and Crooks,S. 2002 Downscaling of global climate models for flood frequency analysis: where are they now ? Hydrological Processes 16: 1137-1150

Reed,M.G. \& Bruyneel,S. 2010 Rescaling environmental governance, rethinking the state: a three-dimensional view. Progress in Human Geography 34(5):646-653.

Rietveld,L.C. Haarhoff,J. and Jagals,P. 2008 A tool for technical assessment of rural water supply systems in South Africa. Physics and Chemistry of the Earth 34: 43-49.

Renzetti,S. 2002 The economics of water demands. Kluwer, Dordrecht.

Rogers,P..P., Ramon Llamas,M.., Martinez-Cortina,L eds. 2006 Water crisis: myth or reality ? Routledge, London.

Rockstrom, J. 2003 Resilience building and water demand management for drought mitigation. Physics and Chemistry of the Earth 28: 869-77

Roth,M. 2007 Review of urban climate research in (sub) tropical regions. International Journal of Climatology 27(14):1859-1873

Ryan,P. 2004 Scaling up - a literature review. IRC International Water and Sanitation Centre (www.irc.nl)

Sanchez,L.D., Sanchez,A., Galvis,G. ande Latorre,J. 2006 Multi-stage filtration. IRC International Water and Sanitation Centre (www.irc.nl)

SDN 2009 Science and Development Network Africa facing climate data shortage 11 November 2009 http://www.scidev.net/en/news/africa-facing-climate-data-shortage.html

Schiermeier,Q. 2010 The real holes in climate science. Nature 463(no. 7279):284-287.

Silverman,B.A. 2003 A critical assessment of hygroscopic seeding of convective clouds for rainfall enhancement. Bulletin American Meteorological Society (Sept.) 1219-1230

Sharp,L. 2006 Water demand management in England and Wales: constructions of the domestic water user. Journal of Environment Planning and Management 49(6): 869-889

Smith,M.S.. 2008 FAO (UN) methods for calculating evaporation and crop water requirements http://www.fao.org/ag/agl/aglw/webpub/REVPUB.htm (accessed 28/1/2008)

Solomon,S. Alley,R. Gregory,R., Lemke,P. and Manning,M. 2008 A closer look at the IPCC report. Science 319 (Jan)409-410.

Soussana,J-F, Graux,A-I \& Tubiello,F.N. 2010 Improving the use of modeling for projections of climate change impacts on crops and pastures. Journal of Experimental Botany 61(8):2217-2228 . 
Stern,N. 2006 Stern review of the economics of climate change. CUP, Cambridge.

Sultana, F. 2009 Fluid lives: subjectivities, gender and water in rural Bangladesh', Gender, Place \& Culture, 16: 4, $427-444$

Swyngedouw, E. (2006) Power, Water and Money: Exploring the Nexus. Human Development report 2006 Occasional Paper. New York: United Nations Development Programme.

Symons, G.E. 2006 Water treatment through the ages. Journal of American Water Works Association 98(3): 87-98

Tebbutt, T.H.Y. 1998 Principles of Water Quality Control. Butterworth Heinemann, Oxford

TERI 2003 Coping with global change. Vulnerability and adaptation in Indian agriculture. The Energy and Resources Institute (TERI), New Delhi. http://www.iisd.org/pdf/2004/climate coping global change.pdf

The Royal Society 2008 Climate change controversies. http://royalsociety.org/uploadedFiles/Royal Society Content/News and Issues/Science Issues/Climate change/Climate booklet RS1420 reprint Dec08.pdf

Therkildsen,O.1988 Watering white elephants ? Scandinavian Institute of African Studies, Uppsala.

Thompson, J., Porras, I., Tumwine, J., Mujwahuzi, M., Katui-Katua, M, Johnstone, N and Wood L. (2001) Drawers of Water II. London: International Institute for Environment and Development.

Thornton PK, Jones PG, Owiyo T, Kruska RL, Herrero M, Kristjanson P, Notenbaert A,Bekele $\mathrm{N}$ and Omolo $\mathrm{A}$, with contributions from Orindi V, Otiende B, Ochieng A, Bhadwal S, Anantram K, Nair S, Kumar V and Kulkar U (2006). Mapping climate vulnerability and poverty in Africa. Report to the Department for International Development, ILRI, PO Box 30709, Nairobi 00100, Kenya. Pp 171.

Twort, A.C. Ratnayaka,D.D. and Brandt,M.J. 2002 Water Supply $5^{\text {th }}$ Edn. ButterworthHeinemann, Oxford.

UNDP 2010 Women's empowerment. United Nations Development Programme. http://www.undp.org/women/

USGS 2010 Water resources in the United States. http://water.usgs.gov/

UNCED 1992 United Nations Conference on Environment and Development, The Earth Summit. Rio de Janeiro. http://www.un.org/geninfo/bp/enviro.html

Van Slobbe,E. Morris,E.D. Roling,N. Torenbeek,R. Broker,K. and Heering,H. 2006 Social Learning in wetland development, Chapter 12 in Bobbink,R. Beltman,B. Verhoeven,J.T.A. and Whigham,D.F. eds. Wetlands: Functioning, biodiversity conservbation aqnd restoration. Ecological Studies Volume 191, p269-283, Springer-Verlag, Berlin

Walski,T.A. 2006 A history of water distribution. American Water Works Association. Journal 98(3):110-121 
Wamsler,C. 2007 Bridging the gaps: stakeholder based strategies for risk reduction and financing for the urban poor. Environment and Urbanization19(1): 115-142

Ward,R. and Robinson,M. 1999 Principles of hydrology $4^{\text {th }}$ edn. McGraw-Hill Higher Education

WCD 2000 World Commission on Dams Report: Dams and Development,

Earthscan. (http: //www.dams.org/report/earthscan.htm)

WCD 2009 World Commission on Dams (http://www.dams.org/)

Were,E., Roy,J. and Swallow,B. 2008 local organisation and gender in water management: a case study from the kenya highlandsJournal of International Development 20: 69-81

White, I. 2008 The Absorbent City: urban form and flood risk management Proceedings of the Institution of Civil Engineers: Urban Design and Plannin., December (DP4), 151 161.

Wilhite, D.A. (ed.). 2000. Drought: A Global Assessment. Natural Hazards and Disasters Series. Routledge, London.

Wirfa,L, Campbell, A and Rea,N. 2008 mplications of gendered environmental knowledge in water allocation rocesses in central Australia. Gender, Place and Culture Vol. 15(5): 505518

World Bank 2009, Water Data and Statistics. World Bank. http://go.worldbank. org/VNZNZY9KZ0 2009, Water Data and Statistics. World Bank. http://go.worldbank. org/VNZNZY9KZ0

WRI 2007 World Resource Institute, Earth trends. http://www.wri.org/

WWC 2000 World Water Council 2nd World Water Forum. The Hague, The Netherlands, March: http://www.worldwatercouncil.org/index.php?id=1594 \&L=0\%2Fst...usuarios.arnet.com.ar\%2FI\%20target\%3D\%20target\%3D\%20 target\%3D\%20target\%3D

WWC 2006 Fourth World Water Forum, Mexico. World Water Council

WWC 2010 World Water Council WRC http://www.worldwatercouncil.org/index.php?id=25

WWDR 2006 UN World Water Development Report, $2^{\text {nd }}$ Report: Water a shared responsibility.UNESCO, Paris. http://www.unesco.org/water/wwap/wwdr/wwdr2/

WWDR 2009 The UN World Water Development Report, $3^{\text {rd }}$. Report: Water in a changing world. UNESCO, Paris. http://www.unesco.org/water/wwap/wwdr/wwdr3/ 